DE DE GRUYTER

OPEN

10.2478/pesd-2014-0008

PESD, VOL. 8, no. 1, 2014

\title{
STUDIES REGARDING THE SAFETY IN OPERATION OF EZER RESERVOIR
}

\author{
Isabela Balan ${ }^{1}$, Irina Dana Tutunaru ${ }^{2}$, Claudiu Pricop ${ }^{2}$, Ioan Balan ${ }^{2}$
}

Key words: dam failure, hydrostatic level, drainage system, behaviour monitoring

\begin{abstract}
The dam of the non-permanent reservoir Ezer, located on Jijia river is an earth dam with a maximum height of $6.18 \mathrm{~m}$, which provides a global retention to the canopy of 10.330 million cubic meters. The dam founded on weak, muddy soils suffered in the years 1989 and 1992 downstream slope failures of the fillings. It was found that hydrostatic levels were high in the piezometric wells and that consolidation of the foundation soil was reduced. This paper presents a brief history of the dam and aspects regarding the behaviour monitoring of Ezer non-permanent reservoir during the years 2000-2012.
\end{abstract}

\section{Brief overview of the reservoir}

\subsection{General data}

Ezer non-permanent reservoir, operated by Prut-Bârlad Water Basinal Administration, is located on Jijia river (national cadastral code XIII.1.15), $16.2 \mathrm{~km}$ downstream of spring river, in Hilişeu-Horia village, upstream of Dorohoi city, in Botoșani county. The reservoir commissioned in November 1996, is mainly aimed to temporary withhold and mitigate flood waves, increase flood defense for the objectives located downstream of the dam.

The retention in Ezer reservoir is made by a frontal, homogeneous earth dam with a canopy length of $750 \mathrm{~m}$, with a double trapezoidal cross section, between the surface outlet and the right bank embedding, and a trapezoidal cross section, between the surface outlet and the left bank embedding. The dam body has a canopy width of $5.0 \mathrm{~m}$. The section between the surface outlet and the right bank embedding has upstream and downstream embankment slope of 1:4 and includes upstream and downstream $27 \mathrm{~m}$ width berms.

\footnotetext{
${ }^{1} \mathrm{PhD}$. Stud. “Gheorghe Asachi” Technical University of Iasi, Romania, isabela.balan@yahoo.co.uk

${ }^{2}$ Prut-Bârlad Water Basinal Administration
} 
The site was chosen taking in consideration the geomorphological and geotechnical features of the section and the nature and properties of the building material, data provided by the geological study prepared by the Research and Design in Water Management Institute - Iasi Branch. The geotechnical studies revealed unfavorable characteristics of the foundation soil and proposed measures to consolidate it in the meadow area and to waterproof the bank embeddings.

In order to descend the seepage curve through the dam a draining ballast mattress was placed on a $0.6 \mathrm{~m}$ width and $471 \mathrm{~m}$ long geotextile layer at the foundation soil. The consolidation of the foundation soil was accelerated by a system of 310 draining wells, arranged in 4 rows in the middle of the meadow, where muddy clay layer is thicker then $20 \mathrm{~m}$. The $16^{\prime \prime}$ nominal diameter wells filled with ballast have an $8.0 \mathrm{~m}$ depth. The top of the wells is placed, on a $0.6 \mathrm{~m}$ depth, in contact with the draining mattress by a network of draining ditches filled with ballast.

Collecting and dripping water from the wells and the draining mattress is achieved through 2 parallel $300 \mathrm{~mm}$ nominal diameter culverts. Between these culverts, on the foundation soil of the downstream berm, $0.7 \mathrm{~m}$ width and $0.5 \mathrm{~m}$ high ballast straps were placed. The connection of the culvert with the draining mattres is made through a a ballast prism with $0,5 \mathrm{~m}$ low base width, $0,5 \mathrm{~m}$ height and 1: 1 downstream slope thus ensuring the continuity of the draining mattress with the ballast straps drainage. (Fig. 1).

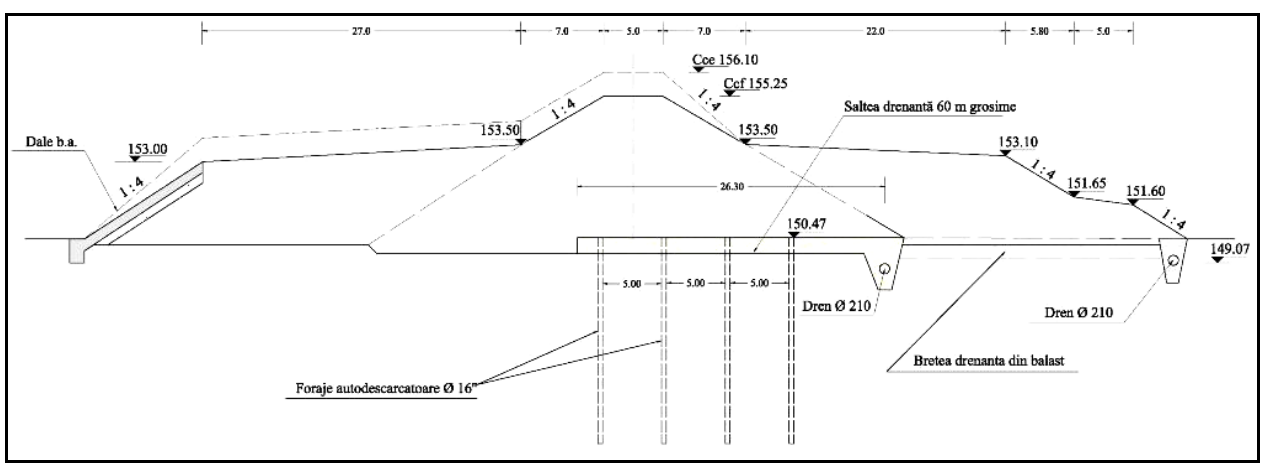

Fig. 1 - Cross section of the dam body - design phase

The downstream drain collector has a reverse filter made of $30 \mathrm{~mm}$ diameter refusal screen. Concrete $1000 \mathrm{~mm}$ diameter manholes are located on the trail of the draining culvert, with a $50 \mathrm{~m}$ distance between them. The water from precipitation that drains on the downstream embankment slope and banks is collected through a 
trench located at the downstream base of the berm dam. The trench discharges in Jijia's old riverbed through an earth canal.

\subsection{Hidrological data}

The reservoir in question falls in the $\mathbf{I I}^{\text {nd }}$ class of importance and $\mathbf{B}$ category of importance. According to the Romanian STAS 4068/2-62, Ezer reservoir was sized using the flow with the probability of exceedance of $1 \%$ and was verified using the flow with the probability of exceedance of $0.1 \%$ with a $20 \%$ increase safety.

Jijia river has the following features (Ministerul Mediului, Atlasul cadastrului apelor din România):

- catchment area in Ezer sealing section $\mathrm{F}=116 \mathrm{~km}^{2}$;

- average altitude $186 \mathrm{~m}$

- river length from spring to dam $\mathrm{L}=16.2 \mathrm{~km}$;

- natural annual average flow $Q_{\mathrm{mm}}=0.320 \mathrm{~m}^{3} / \mathrm{s}$

Characteristics of flood waves from design phase and updated in 2010 are presented in Table 1.

Tab. 1 - Characteristics of flood waves

\begin{tabular}{|l|c|c|}
\hline Characteristics of flood waves & Design phase & Updated 2010 \\
\hline $1,2 \times 0,1 \%$ probability flow - cubic meters per second & - & 354 \\
\hline $0,1 \%$ probability flow - cubic meters per second & 300 & 295 \\
\hline $1 \%$ probability flow - cubic meters per second & 160 & 170 \\
\hline Total time - hours & 49 & 40 \\
\hline Increase time - hours & 9.5 & 10 \\
\hline Form factor $\gamma$ & 0.3 & 0.35 \\
\hline $1,2 \times 0,1 \%$ probability volume - million cubic meters & - & 17.842 \\
\hline $0,1 \%$ probability volume - million cubic meters & 16.850 & 14.860 \\
\hline $1 \%$ probability volume - million cubic meters & 8.980 & 8.568 \\
\hline
\end{tabular}

\subsection{Geological characteristics of the site}

From geomorphological point of view the area occupied by Ezer nonpermanent reservoir belongs to Moldavian Plateau, subland structural plateaux, subunit Moldavian Plain. Jijia river floodplain width is relatively large, between 300 and $600 \mathrm{~m}$ and has a longitudinal slope of $1 \%$.

In the damming sections of Jijia river, the slopes aren't affected by landslides. The analyzed valley presents a relatively large major bed with a width of 550-600 $\mathrm{m}$. Its surface is generally smooth, uniform and shows a clear gradient, low slope, from the right side to the left. Existing land rates in the floodplain are higher by 2-4 
$m$ than those at a few hundred meters upstream. This situation is caused by Pârâul Întors river, which filled the confluence with Jijia river with a considerable amount of silt. The floodplain is affected by light marsh processes due to low flow springs coastal. Jijia riverbed, with a width of 8-10 m and a depth of 1.2-1.5 m, is shifted to the left slope, due to the cone of dejection of Pârâul Întors.

The floodplain alluvial deposits, which extend over a thickness of about 28 $\mathrm{m}$, have the following limits of variation for land features:
- plasticity index
$53-99 \%$
- consistency index
$0.21-0.71$
- humidity
$48-99 \%$
- volumetric weight
$12.4-17.0 \mathrm{KN} / \mathrm{mc}$
- porosity
$58-82 \%$
- specific settlement
$6-22 \mathrm{~cm} / \mathrm{m}$
- internal friction angle
6 - 22 grade
- cohesion
$0.1-0.13 \mathrm{daN} / \mathrm{cm}^{2}$

\subsection{Component works of Ezer reservoir}

a) The dam

The dam is homogeneous type, but has specific sealing constructions of the dam body in the embeddings with bentonite mud screen.

b) The surface outlet, a block called "Weir Crocodile", has incorporated an operation tower, also attached to the dam body.

> Structural elements: "crocodile weir" type overflow, frontal, with 2 discharge thresholds, energy disipator, gravel channel, connecting earth channel;

Surface outlet dimensions: total length $151 \mathrm{~m}, \mathrm{I}^{\text {st }}$ threshold discharge front length $=32.0 \mathrm{~m}, \mathrm{II}^{\text {nd }}$ threshold discharge front length $=8.0 \mathrm{~m}$ (Fig. 2).

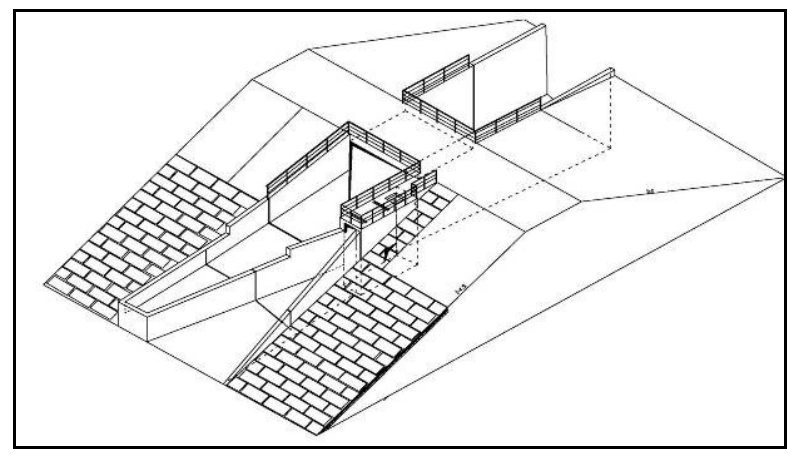

Fig. 2 - Axonometric view of the surface outlet 
c) Bottom outlet has an acces channel to the operation tower and a $1.0 \times 1.0$ $\mathrm{m}$ orifice placed in the joint wall of the weir and the body dam. The water is released directly into the evacuation weir channel. Hydraulic equipment for the bottom outlet consists of fixed parts (guides and actuator) and mobile parts: hoist

$>$ metalic grid: 1000x1260 mm pannel manually operated by dragging the

$>$ cofferdam with guide wheels manually operated operation by dragging the hoist

$>$ flat slide gate for draining the lake with dimensions of 1340x1100 mm, operated manually with normal position open.

\subsection{Characteristic levels and volumes}

The land rates reference plan is Black Sea 1975 and were updated by topographic measurements performed by specialized staff from the Prut-Barlad Water Basinal Administration on the lake basin, dam body and related constructions in 2010 (Tab. 2).

Tab. 2 - Characteristic levels and volumes

\begin{tabular}{|c|c|c|}
\hline Parameters & Characteristic levels & maBS \\
\hline \multirow{4}{*}{$\begin{array}{l}\text { Parameters determined } \\
\text { by structural } \\
\text { characteristics }\end{array}$} & - bottom outlet sill & 149.40 \\
\hline & - surface outlet - ${ }^{\mathrm{st}}$ threshold weir & 152.63 \\
\hline & - surface outlet - II ${ }^{\text {nd }}$ threshold weir & 153.16 \\
\hline & - dam canopy & 154.38 \\
\hline \multirow{3}{*}{$\begin{array}{l}\text { Parameters determined by } \\
\text { the operating conditions }\end{array}$} & $-1 \%$ probability of exceedance & 153.27 \\
\hline & $-0.1 \%$ probability of exceedance & 154.10 \\
\hline & $-1.2 \times 0.1 \%$ probability of exceedance & 154.41 \\
\hline Parameters & Volumes & mil cm \\
\hline \multirow{3}{*}{$\begin{array}{l}\text { Parameters determined by } \\
\text { structural characteristics }\end{array}$} & - global (at dam canopy) & 10.33 \\
\hline & - at high waters weir $-I^{\text {st }}$ threshold & 5.967 \\
\hline & - at high waters weir - II ${ }^{\text {nd }}$ threshold & 7.243 \\
\hline \multirow{3}{*}{$\begin{array}{l}\text { Parameters determined } \\
\text { by the operating } \\
\text { conditions }\end{array}$} & - total (at $1.2 \times 0.1 \%$ probability of exceedance level) & 9.602 \\
\hline & - atennuation till high waters weir $-I^{\text {st }}$ threshold & 5.967 \\
\hline & $\begin{array}{l}\text { - saftey (between the } 1.2 \times 0.1 \% \text { probability of exceedance } \\
\text { level and dam canopy) }\end{array}$ & 0.727 \\
\hline
\end{tabular}

\section{Component elements of the behaviour monitoring system for ezer non- permanent reservoir}

According to the current Romanian legislation (NTLH-021/2002) Ezer dam has a 0.34 risk index (established in the Evaluation of Ezer reservoir safety in exploitation and the Authorization number 566/25.07.2008), that fits the reservoir in „B- special”, category of importance. Monitoring behaviour is done accordingly to the „Project of special monitoring”. 


\subsection{Measuring installations for external stresses}

-2 vertical hydrometric stations are used to monitor hydrological parameters for Ezer reservoir: lake;

- upstream dam slope for tracking the evolution of the levels/volumes in the

- in the joint channel of the bottom outlet channel and the surface outlet, for tracking discharged flows;

- 1 rain gauge to measure rainfalls in the catchment of the reservoir;

- 10 landmarks are placed on the lake contour for tracking the evolution of lake basin warping.

\subsection{Measuring installations of the dam response to stress}

The measuring installations of the dam and its foundation are mainly distributed in 4 major characteristic sections, marked with I-I.....IV- IV.

- $\quad$ For tracking the evolution of vertical deformations are used:

- 40 vertical axis landmarks on the dam, of which 14 on the canopy and 26 on the 2 berms (upstream and downstream slope);

- 6 fixed landmarks;

- 4 landmarks on the operation tower;

- 4 inclinometer columns; are used;

- $\quad$ For tracking the evolution of body dam seepage, 8 piezometric wells

- To measure the interstitial pressures in the foundation soil 14 piezometers are used. They are placed in 8 wells, each of them containing 1 or 3 thin tubes (Fig. $3)$.

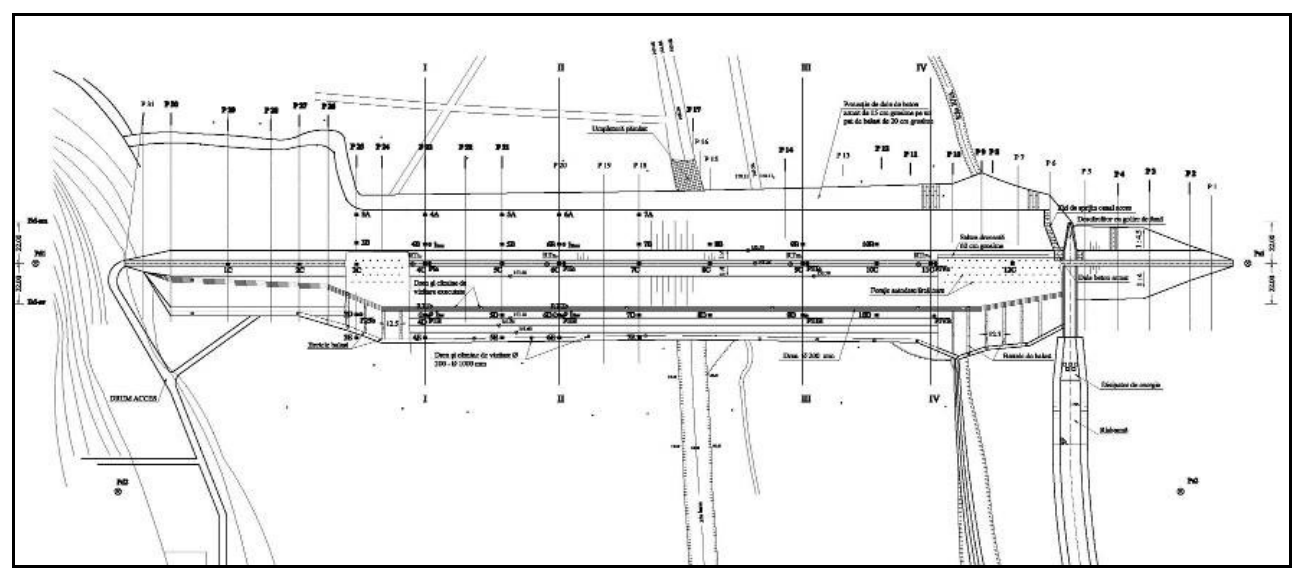

Fig. 3 - Dam body plan view with the location of the measuring installations 


\section{Recording and analysis of special events in ezer reservoir behaviour}

3.1 Special events recorded during the execution of the dam

Given the unfavorable conditions of the foundation soil of the dam, the design phase documentation stipulated the execution of an experimental embankment equipped with measuring installations for the interstitial pressures and the vertical deformations in the foundation soil. This embankment was aimed to specify characteristic elements regarding the stability and behavior of the dam, in line with the development of the foundation soil consolidation. Thus, thin piezometric wells and columns with settlement landmarks were installed.

- In the fall of 1989, there was a failure on the downstream slope of the dam, in the experimental embankment area, on a $3.50 \mathrm{~m}$ height of the dam body fillings.

The construction of the dam was resumed in the year 1992. In may 1992 a new dam failure occured in the area between the experimental embankment and the right slope. This new dam fillings failure, towards the downstream side of the dam, was similar to the one that occured in 1989.

The behavior monitoring of the dam and the foundation soil in the characteristic sections equipped with measuring installations revealed during the years 1989-1992:

- Decrease of the interstitial pressures is insignificant in this time interval. During dam failure in October 1989, pore water pressures in the foundation soil were at the fillings level, exceeding it in some cases, with $0.50-1.00 \mathrm{~m}$. Two years after cessation of construction works, no significant reductions in water level in piezometers were observed. It was found that the consolidation of the foundation soil is reduced.

- The compaction measurements reveal the presence of a weak layer in the dam foundation soil, comprised approximately between 4 and $8 \mathrm{~m}$ depth. In this layer the compaction were bigger than the adjacent layers. It was found that the effects of the dam failure extended about $7 \mathrm{~m}$ below the dam foundation.

In order to continue the construction works of the dam, the The National Institute for Research and Development in Environmental Protection (former I.C.I.M.) performed stability calculations for a new cross section design of the dam. During the period August 1995 - April 1996 several series of measurements in columns with compaction landmarks, inclinometer and piezometric wells were conducted.

- $\quad$ In 8 months of measurements, settlements of 3-9 $\mathrm{cm}$ were recorded.

- It was found that the horizontal displacements were small (maximum 20-25 mm).

The technical regulations require that stability tracking methods of the embankments placed on weak, muddy foundation soils to be based on the study of 
maximum settlements measured in the central area of the fillings and of horizontal deformations of the foundation soil measured at the base of the slope. The ratio of horizontal and vertical deformation should be less than 1 , preferably 0.5 . The measured deformations satisfy the above conditions of stability.

- The highest interstitial pressures were registered in the $\mathrm{I}^{\text {st }}$ characteristic section. The low depth piezometric wells with the upper land rate of $140.00 \mathrm{maBS}$ have shown high hydrostatic levels corresponding to canopy level and the downstream berm. Other piezometric wells in the $\mathrm{I}^{\text {st }}$ and the $\mathrm{II}^{\text {nd }}$ characteristic sections have also indicated relatively high interstitial pressures, the hydrostatic levels exceeded foundation level and water level in the lake. In the III ${ }^{\mathrm{rd}}$ and $\mathrm{IV}^{\text {th }}$ characteristic section, the hydrostatic levels were lower, compared to the $\mathrm{I}^{\mathrm{st}}$ and the II $^{\text {nd }}$ characteristic sections.

In terms of general stability, the measurements showed that general stability is ensured and that the critical period "end of the construction" has been exceeded.

\subsection{Special events recorded during operation}

Starting with the year 2002, 5 periods of floods were recorded in Ezer reservoir. The exceedance of the characteristic defense thresholds is shown below:

-152.66 maBS, $0.16 \mathrm{~m}$ above the II $^{\text {nd }}$ Defense Phase (152.50 maBS) in $03 / 28 / 2002$

$\bullet 153.09 \mathrm{maBS},+0.09 \mathrm{~m}$ above the III $^{\text {rd }}$ Defense Phase (153.00 maBS $-\mathrm{I}^{\mathrm{st}}$ threshold weir of the surface outlet) in 08/21/2005

$\bullet 152.54 \mathrm{maBS},+0.04 \mathrm{~m}$ above the $\mathbf{I I}^{\text {nd }}$ Defense Phase (152.50 maBS) in $04 / 04 / 2006$

- $\quad 153.13 \mathrm{maBS},+0.13 \mathrm{~m}$ above the III $^{\text {rd }}$ Defense Phase (153.00 maBS I ${ }^{\text {st }}$ threshold weir of the surface outlet) in 06/06/2006

- $\quad 153.93 \mathrm{maBS},+0.43 \mathrm{~m}$ above the $\mathbf{I I}^{\text {nd }}$ threshold weir of the surface outlet in $06 / 29 / 2010$

On 06/28/2010 due to the rainfalls registered at Pădureni rain gauge (42.2 liters per square meter), there was a flash flood on Buhai river, in addition with the one formed on Pârâul Întors river, which inundated the Dorohoi city lower area and caused the accumulation of large volumes of water downstream Ezer reservoir's embankment. The backwater, formed on Jijia river, caused significant increases of water levels in Ezer reservoir, starting 06/28/2010 - $18^{00}$ hour.

Starting $06 / 29 / 2010-01^{00}$ hour, in the artificially created reservoir downstream of the dam, the water level exceeded the $\mathrm{I}^{\text {st }}$ threshold weir of the surface outlet (153.00 maBS) and on the downstream to upstream direction, an overflow spillway occurred, until 07/01/2010 $-12^{00}$ hour. The maximum height of the spill over the It threshold weir of the surface outlet (153.00 maBS) was $93 \mathrm{~cm}$ and the maximum height of the spill over the II ${ }^{\text {nd }}$ threshold weir of the surface outlet (153.50 maBS) 
was $43 \mathrm{~cm}$. The maximum water level in the reservoir of $153.93 \mathrm{maBS}$ was maintained for a gap of 2 hours, from $06 / 29 / 2010-05^{00}$ hour. The water level of Buhai river and the water volume accumulated downstream of the dam began to decrease gradually, and so on the date of $07 / 12 / 2010-18^{00}$ hour, the water level in Ezer reservoir decrease below the $\mathbf{I}^{\text {st }}$ Defense Phase (152.30 maBS).

The piezometric wells, located on the downstream berm of the dam, and also the inclinometer wells and the columns with compaction landmarks located on the upstream berm were flooded. Between the years 2000-2010, the culvert from the draining mattress worked under pressure, due to the clogging of the culvert draining channel and the operation personnel was unable to carry out measurements of flow seepage.

After the flood that occurred during June-July 2010, the following repairs and maintenance works were carried out in August 2010:

-unclogging the trench located downstream of the dam

-unclogging the seepage discharge channel to its confluence with Jijia river -unclogging the regulated section of Jijia river downstream of the reservoir -unclogging the manholes from the drainage system

-sediment exclusion of the piezometric wells, inclinometer wells and the columns with compaction landmarks, located on the upstream berm.

\section{Analysis of the safety in operation of the reservoir and results}

4.1. External stresses recorded during the years 2000 - 2012

The database containing water levels in reservoir, rainfalls, temperatures, floods recorded between the years 2000-2012, provided by the Prut-Barlad Water

Tab. 3 - External stresses between the years 2000 and 2012

\begin{tabular}{|c|c|c|c|c|c|c|c|c|c|}
\hline \multirow{3}{*}{ Year } & \multicolumn{3}{|c|}{ Water level (maBS) } & \multirow{3}{*}{$\begin{array}{l}\text { Level } \\
\text { diff. } \\
\text { (m) }\end{array}$} & \multicolumn{3}{|c|}{ Precipitations (mm) } & \multirow{3}{*}{$\begin{array}{c}\text { Average } \\
\text { temperature } \\
{ }^{0} \mathrm{C}\end{array}$} & \multirow{3}{*}{ Floods } \\
\hline & \multirow{2}{*}{$\begin{array}{l}\text { Max } \\
\text { level }\end{array}$} & \multirow{2}{*}{$\begin{array}{l}\text { Min } \\
\text { level }\end{array}$} & \multirow{2}{*}{$\begin{array}{c}\text { Average } \\
\text { level }\end{array}$} & & \multirow{2}{*}{$\begin{array}{l}\text { Year } \\
\text { Total }\end{array}$} & \multicolumn{2}{|c|}{ Maximmum } & & \\
\hline & & & & & & monthly & daily & & \\
\hline 2000 & 150.92 & 149.75 & 149.97 & 1.17 & 299.4 & 118.4 & 62.4 & 10.82 & \\
\hline 2001 & 151.06 & 149.88 & 150.28 & 1.18 & 533.3 & 145.3 & 56 & 9.63 & \\
\hline 2002 & 152.66 & 150.87 & 151.57 & 1.79 & 549.9 & 186.6 & 44 & 9.98 & $+0.16 \mathrm{mII}^{\text {nd }} \mathrm{DP}$ \\
\hline 2003 & 151.79 & 150.26 & 150.50 & 1.53 & 329.8 & 95.4 & 28.8 & 8.22 & \\
\hline 2004 & 150.92 & 150.00 & 150.49 & 0.92 & 325.2 & 70.7 & 23 & 9.95 & \\
\hline 2005 & 153.09 & 149.86 & 150.30 & 3.23 & 761.8 & 304.1 & 57.9 & 9.22 & $+0.09 \mathrm{~m} \mathrm{I}^{\mathrm{st}}$ Weir \\
\hline 2006 & 153.13 & 149.84 & 150.65 & 3.29 & 679.6 & 194.8 & 51.8 & 9.15 & $+0.13 \mathrm{~m} \mathrm{I}^{\mathrm{st}}$ Weir \\
\hline 2007 & 150.70 & 149.83 & 150.02 & 0.87 & 597.2 & 106.8 & 38.3 & 10.78 & \\
\hline 2008 & 150.70 & 149.83 & 150.02 & 0.87 & 669.5 & 153.7 & 51.1 & 10.77 & \\
\hline 2009 & 150.96 & 149.70 & 149.98 & 1.26 & 445.9 & 87 & 38.2 & 10.80 & \\
\hline 2010 & 153.93 & 149.71 & 150.11 & 4.22 & 811.8 & 208.5 & 67.3 & 9.65 & $+0.43 \mathrm{~m} \mathrm{II} \mathrm{II}^{\text {nd }}$ Weir \\
\hline 2011 & 150.36 & 149.60 & 149.77 & 0.76 & 339.9 & 111.7 & 21.9 & 9.86 & \\
\hline 2012 & 149.89 & 149.60 & 149.68 & 0.29 & 432.5 & 101.2 & 34.2 & 12.95 & \\
\hline
\end{tabular}


Basinal Adminstration, was used for the interpretation of the reservoir behaviour (Tab. - 3).

\subsection{Visual observations}

a) Integrity of the structure, including the foundation and the embankments

The visual observations made by the operations personnel didn't reveal any structural changes of the dam's body and foundation or of the embankments.

b) Reservoir and embankments

No changes in embankments or lake bordeline geometry were reported and no ravines, landslides or leakings were revealed.

c). Outlets

During the floods that occurred during 06/29-07/12/2010, the degradation of concrete slabs pitching near the left wall of the overflow spillway has produced. Remediation works were applied.

d) Status of the upstream and downstream channels

From visual observations made post-event (june-july 2010 flood) by the operation personnel at the downstream riverbed, the silting of river Jija was revealed on the rectified section downstream Ezer reservoir, on a length of $1 \mathrm{~km}$, with a $1 \mathrm{~m}$ thick alluvial deposit.During the year 2011, unclogging works were carried out.

\section{e) Acces ways}

The access ways to the dam haven't suffered incidents affecting their use.

f) Hydromechanical equipments

The hydromechanical equipments have a good operation status.

\subsection{Evolution of monitored parameters}

Geotechnical studies drawn during the design phase for Ezer reservoir revealed unfavorable characteristics of the foundation soil, which is characterized by high values of clay fraction and plasticity. Up to a maximum depth of $25 \mathrm{~m}$, the foundation soil consists of gray to black greasy clays. Improvement of the dam stability and acceleration the consolidation of the muddy clays in site and foundation soil was achieved with the construction of the drainage system that has the role of direct dissipation of excess interstitial pressures.

Given the incident that occurred during the execution of the hydrotechnical work, the dam was equipped with relatively simple behaviour monitoring installations, that includes piezometric thin tubes with porous ceramic cell, columns with compaction landmarks, inclinometers, vertical axis landmarks placed on the dam canopy and on the upstream and downstream berms. 


\section{a) Seepage regime}

Hydrostatic levels in the piezometric wells were the first response of dam body to the external stresses: reservoir water level variations, rainfalls and temperatures. The seepage regime through dams' body and foundation soil was also influenced.

The measuring installations were distributed on the dam mainly in 4 characteristic sections as noted I-I. ....IV-IV. The piezometric wells marked with Pic1, PIIc1, PIIIc1, PIVc1 - c4, located on the dam canopy and PIb1, PIIb1, PIVb1 located on the downstream berm, were designed to capture the seepage regime through the dam body. Piezometric wells of different depths PIc2 - 3, PIb2 - 3 PIIc2 - c3, PII b2 - 3 PIIIc2 - c3, PIIIb2 - b3, PIVc2-3 enter in the foundation soil and are designed to dissipate interstitial pressures in the foundations' muddy soil.

Primary processing of recorded data, revealed increases and decreases of the hydrostatic levels in the foundation soil in the canopy piezometric wells noted with c2, c3 and also in the piezometric wells noted with b2, b3 placed on the berm. These variations represent the response in time, mainly of dissipation of the interstitial pressures in the foundation soil and less the response in time of the variations of water level in the reservoir, which is operated as a non-permanent reservoir.

Hydrostatic levels in PIb1, PIc4, PIIb1, PIIIb3 piezometric wells were strongly influenced by the rainfalls produced in June 2010. Differences of over 0.5 $\mathrm{m}$ from the previous readings of the hydrostatic levels were highlighted. Measurements were performed at increased frequency in these piezometric wells and it was found that the storm water infiltration near the tube had caused high hydrostatic level. It can be concluded that the interstitial pressures in the foundation soil is consistently higher for the deepest piezometric wells located on the downstream berm (PIIb3 - 14.25 m depth, PIb3 - 8.5 m depth, PIb2 - 6.98 m depth).

The depression curves close in the downstream area of the dam, in the draining straps.

We believe that the consolidation of the foundation (poor, muddy soil) is still in progress. This phenomenon may extend for periods of tens of years, resulting in vertical deformations in the deep muddy layers of foundation soil and hence centimeters deep settlements of the dam body.

Buhai creek repeated overflows contributed to the clogging of drainage channel of Ezer reservoir, because it confluences with Jijia river in the immediate downstream vicinity of the dam. During the years 2000-2010, the culvert of the draining mattress has worked under presssure and the operation personnel was unable to carry out measurements of flow seepage. Since August 2010 
measurements of seepage flow were carried out, the extreme values being 0.0283 $\mathrm{m} / \mathrm{s}$ and $0.0783 \mathrm{~m} / \mathrm{s}$.

\section{b) Compactions}

On the dam canopy, 38 landmarks were planted in the year 1996 and the reference series "0" was carried out on 02/11/1997. In the period of 02/11/1997 10/29/2011, 32 cycles of observation were carried out. Analyzing the latest data, we have concluded that the relative values of the settlements were almost constant compared to the previous measurements. The maximum and minimum absolute values of vertical deformations indicate that the dam has not yet reached its maximum degree of compaction, this phenomenon is far more active in comparison with other dams, in which compaction has decreased.

\section{Conclusions}

The special events recorded during the execution of the dam and during its operation have imposed the implementation of a systematic behaviour monitoring of the hydrotechnic constructions at Ezer reservoir.

The behaviour monitoring performed by interpreting the visual observations and the measurement data from gauges, in relation to external stresses on the dam, allowed rapid reporting of exceedances of critical thresholds at monitored elements and of a typical behaviours of the dam.

The operation personnel intervened with remediation works on the faults that endangered the safe operation of the dam.

The behaviour monitoring of Ezer reservoir is recommended to continue accordingly to the "Project of special monitoring", with the same meticulosity as before.

\section{References}

Ministerul Mediului, (1992), Atlasul cadastrului apelor din România, Editura Romcart S.A., București 448

Comitetul Român al Marilor Baraje din România, (2000) Baraje din România, Casa Editorială Univers Enciclopedic, Bucureşti

Ministerul Mediului şi Dezvoltării Durabile, (2008) Inventarul barajelor care realizează acumulări de apă - REBAR

Stematiu D., Ionescu Şt., Abdulamit A., (2010) Siguranţa barajelor şi Managementul riscului, Editura Conspress, Bucureşti

Giurma I., Crăciun I., Giurma Catrinel Raluca, (2003) Hidrologie şi hidrogeologieaplicaţii, Universitatea Tehnică „Gh. Asachi”,Iaşi.

Giurma I., (2003) Viituri şi măsuri de apărare, Editura Gheorghe Asachi, Iasi

Băloiu V., (1971) Gospodărirea Apelor, Editura Didactică şi Pedagigică, Bucureşti 
Popovici A., (2002) Baraje pentru acumulări de apă - Vol. II, Editura Tehnică, Bucureşti

Bobocu D., (2009) Evaluarea siguranţei barajelor pentru acumulări de apă pe baza prelucrării statistice ale datelor furnizate de aparatura de supraveghere. Teză de doctorat, UTCB

Administrația Bazinală Prut - Bârlad, (2010) Regulamentul de exploatare al acumulării Ezer

Administraţia Bazinală Prut - Bârlad, (2012) Raportul de sinteză privind urmărirea comportării construcţiilor la acumularea Ezer, perioada de analiză aprilie 2010 februarie 2012

Administrația Bazinală Prut - Bârlad, (2012) Proiect de urmărire specială a acumulării Ezer

Administraţia Bazinală Prut - Bârlad, (2013) Raport anual de sinteză privind activitatea de urmărirea comportării construcțiilor din patrimoniul Administrației Bazinale de Apă Prut - Bârlad în anul 2012 
